\title{
$298 \mathrm{~K}$ rate coefficients for the reaction of $\mathrm{OH}$ with $i-\mathrm{C}_{3} \mathrm{H}_{7} \mathrm{I}$, $n-\mathbf{C}_{3} \mathbf{H}_{7} \mathbf{I}$ and $\mathbf{C}_{3} \mathbf{H}_{8}$
}

\author{
S. A. Carl ${ }^{1}$ and J. N. Crowley ${ }^{2}$ \\ ${ }^{1}$ Department of Chemistry, University of Leuven, Celestijnenlaan 200F, B-3001 Leuven, Belgium \\ ${ }^{2}$ Max-Planck-Institut für Chemie, Division of Atmospheric Chemistry, Postfach 3060, D-55020 Mainz, Germany
}

Received 13 July 2001 - Published in Atmos. Chem. Phys. Discuss. 3 September 2001

Revised 2 November 2001 - Accepted 6 November 2001 - Published 22 November 2001

\begin{abstract}
The kinetics of the title reactions were investigated using the laser photolysis - resonance fluorescence method, employing the sequential two-photon dissociation of $\mathrm{NO}_{2}$ in the presence of $\mathrm{H}_{2}$ as the $\mathrm{OH}$ source. The $298 \mathrm{~K}$ rate constant for $\mathrm{OH}+\mathrm{C}_{3} \mathrm{H}_{8}$ was found to be $(1.15 \pm 0.1)$ $\times 10^{-12} \mathrm{~cm}^{3} \mathrm{~s}^{-1}$, in excellent agreement with the literature recommendation, and with a separate determination using $\mathrm{HNO}_{3}$ photolysis at $248 \mathrm{~nm}$ as the $\mathrm{OH}$ source. The $298 \mathrm{~K}$ rate constants for $\mathrm{OH}+n-\mathrm{C}_{3} \mathrm{H}_{7} \mathrm{I}$ and $i-\mathrm{C}_{3} \mathrm{H}_{7} \mathrm{I}$ were measured for the first time and found to be $(1.47 \pm 0.08)$ and $(1.22 \pm 0.06) \times 10^{-12} \mathrm{~cm}^{3} \mathrm{~s}^{-1}$, respectively. The errors include an assessment of systematic error due to concentration measurement, which, for the propyl-iodides was minimised by on-line UV-absorption spectroscopy. These results show that reaction with $\mathrm{OH}$ is an important sink for $n-\mathrm{C}_{3} \mathrm{H}_{7} \mathrm{I}$ and $i-\mathrm{C}_{3} \mathrm{H}_{7} \mathrm{I}$, which has implications for the reactive iodine budget of the marine boundary layer.
\end{abstract}

\section{Introduction}

Iodine compounds play an important role in the chemistry of the marine boundary layer (MBL) (Chameides and Davis, 1980; Jenkin et al., 1985; Chatfield and Crutzen, 1990; Jenkin, 1993; Davis et al., 1996; Vogt et al., 1999; McFiggans et al., 2000). The major source of iodine are biogenic alkyl-iodides such as $\mathrm{CH}_{3} \mathrm{I}$, (Singh et al., 1983; Happell and Wallace, 1996) which is produced by metabolic processes in macroalgae and phytoplankton, and released from the ocean to the atmosphere. Recent measurements also indicate the presence of larger alkyl-iodides, with surprisingly high average concentrations of gas-phase $i-\mathrm{C}_{3} \mathrm{H}_{7} \mathrm{I}$ (up to $2 \mathrm{ppt}$ ) found in the Arctic troposphere and both $i-\mathrm{C}_{3} \mathrm{H}_{7} \mathrm{I}$ and $n-\mathrm{C}_{3} \mathrm{H}_{7} \mathrm{I}$ being detected in Arctic sea-water samples

Correspondence to: J. N. Crowley

(crowley@mpch-mainz.mpg.de)
(Schall and Heumann, 1993; Vogt et al., 1999). In addition, multiply-substituted alkyl-iodides such as $\mathrm{CH}_{2} \mathrm{I}_{2}$ (Carpenter et al., 1999) have been observed, which indicates a stronger overall emission of inorganic iodine to the marine atmosphere than previously assumed. The generation of reactive inorganic iodine species from these organic compounds occurs mainly via photodissociation, with lifetimes varying from $200 \mathrm{~s}$ to $90 \mathrm{hrs}$ (Roehl et al., 1997) to yield iodine atoms, I. The dominant fate of I in the atmosphere is reaction with ozone to form the iodine oxide radical, IO, which can take part in gas-phase, ozone destroying reaction cycles. Recent measurements of IO at a number of coastal locations (Alicke et al., 1999; Stutz et al., 1999; Allan et al., 2000) support the concept of an active iodine chemistry over large parts of the marine atmosphere. The $\mathrm{OH}$ radical is the primary initiator of oxidation in the troposphere and its concentration determines the lifetimes, and thus the abundance of most naturally and anthropogenically emitted chemical species (Crutzen, 1983) including $\mathrm{CH}_{4}$ and also non-methane hydrocarbons. For multiply substituted alkyl-iodides, the absorption spectrum extends well into the actinic region, and the reaction with $\mathrm{OH}$ is not likely to contribute significantly to their degradation. In contrast, the mono-substituted alkyliodides have considerably longer photolytic lifetimes, and reaction with $\mathrm{OH}$ may compete with photolysis. The greatest potential for reaction with $\mathrm{OH}$ will be associated with those alkyl- iodides that possess a large number of relatively weak $\mathrm{C}-\mathrm{H}$ bonds. Given the trend in $\mathrm{OH}$ rate constants with $\mathrm{CH}_{4}$, $\mathrm{C}_{2} \mathrm{H}_{6}$ and $\mathrm{C}_{3} \mathrm{H}_{8}$, which varies from $6.2 \times 10^{-15}\left(\mathrm{CH}_{4}\right)$ to $2.5 \times 10^{-13}\left(\mathrm{C}_{2} \mathrm{H}_{6}\right)$ and $1.1 \times 10^{-12} \mathrm{~cm}^{3} \mathrm{~s}^{-1}\left(\mathrm{C}_{3} \mathrm{H}_{8}\right)$ at $298 \mathrm{~K}$, respectively (Atkinson et al., 1997), $n-\mathrm{C}_{3} \mathrm{H}_{7} \mathrm{I}$ and $i-\mathrm{C}_{3} \mathrm{H}_{7} \mathrm{I}$ would appear to be the best choice for investigation. At present, although the lifetimes of $n-\mathrm{C}_{3} \mathrm{H}_{7} \mathrm{I}$ and $i-\mathrm{C}_{3} \mathrm{H}_{7} \mathrm{I}$ with respect to photodissociation have been calculated, the rate constants for reaction with $\mathrm{OH}$ are unknown. The aims of the present study were therefore to make the first measurements of the rate constants for the reaction of 


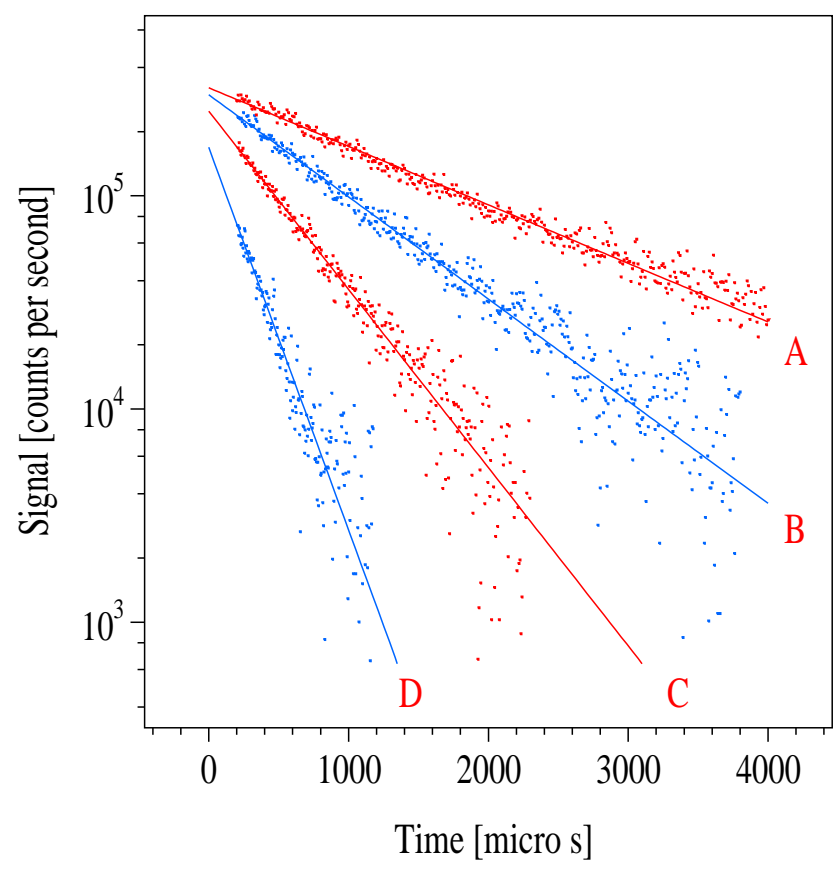

Fig. 1. Exponential decays of $\mathrm{OH}$ in the presence of various excess concentrations of $\mathrm{C}_{3} \mathrm{H}_{8}$. The concentrations of $\mathrm{C}_{3} \mathrm{H}_{8}\left(\right.$ in $\mathrm{cm}^{-3}$ ) were: $\mathrm{A}=0 ; \mathrm{B}=4.10 \times 10^{14}, \mathrm{C}=1.12 \times 10^{15}, \mathrm{D}=3.12 \times 10^{15}$.

$\mathrm{OH}$ with $n-\mathrm{C}_{3} \mathrm{H}_{7} \mathrm{I}(1)$ and $i-\mathrm{C}_{3} \mathrm{H}_{7} \mathrm{I}$, (2) at room temperature. As a test of our experimental methodology, we have re-measured the rate constant of the well characterised reaction between $\mathrm{OH}$ and propane (3) at the same temperature.

$$
\begin{aligned}
& \mathrm{OH}+n-\mathrm{C}_{3} \mathrm{H}_{7} \mathrm{I} \rightarrow \text { products } \\
& \mathrm{OH}+i-\mathrm{C}_{3} \mathrm{H}_{7} \mathrm{I} \rightarrow \text { products } \\
& \mathrm{OH}+\mathrm{C}_{3} \mathrm{H}_{8} \rightarrow \text { products }
\end{aligned}
$$

\section{Experimental}

\subsection{General}

The laser photolysis / OH-resonance fluorescence experimental set-up has been described in detail in recent publications (Crowley et al., 1996; Carl and Crowley, 1998). Pulsed (5-6 ns) radiation at $439.44 \mathrm{~nm}$ was provided by a Nd-YAG pumped dye-laser operating at $10 \mathrm{~Hz}$ with coumarin 120 dye. The laser emission was expanded to a collimated beam of about $5 \mathrm{~mm}$ diameter and passed through 3 irises of $\approx 4 \mathrm{~mm}$ diameter before entering the photolysis cell through a quartz window at the Brewster angle. Pulse energies were monitored with a Joule meter placed behind the exit Brewster window of the cell. $\mathrm{OH}$ radicals were excited by a microwave powered discharge lamp (flowing mixture of $\mathrm{H}_{2} \mathrm{O}$ in $\mathrm{He}$ at 3 Torr) and their fluorescence detected at right angles to both the axis of propagation of the laser beam and the microwave lamp by a photomultiplier operating in photon counting mode which was screened by a $309 \pm 5 \mathrm{~nm}$ interference filter. Between 1000 and 5000 decay profiles were averaged at 10 $\mathrm{Hz}$ to improve signal-to-noise ratios.

The concentrations of $i-\mathrm{C}_{3} \mathrm{H}_{7} \mathrm{I}$ and $n-\mathrm{C}_{3} \mathrm{H}_{7} \mathrm{I}$ were determined by their absorption of UV light $\left(\mathrm{D}_{2}\right.$ lamp) in a separate cell of $174 \mathrm{~cm}$ optical path length, which was connected serially in flow prior to the photolysis cell and maintained at room temperature. The entire absorption region of $n-\mathrm{C}_{3} \mathrm{H}_{7} \mathrm{I}$, and $i-\mathrm{C}_{3} \mathrm{H}_{7} \mathrm{I}$ between 220 and $380 \mathrm{~nm}$ was recorded by diode array spectroscopy, and concentrations determined by least-squares fitting to uv-absorption spectra measured in this laboratory (Roehl et al., 1997). For propane, which does not absorb in the UV, the concentration was determined by calculating a mixing ratio based on relative and total flows through calibrated mass flow controllers and the total pressure, determined by capacitance manometer. The concentration of $\mathrm{NO}_{2}$ was also occasionally determined by its optical absorption around $400 \mathrm{~nm}$, although this parameter is not necessary for the extraction of rate data in the kinetic experiments.

The Teflon-coated, stainless steel photolysis cell is equipped with a thermostatted glass gas inlet and is itself maintained at $298 \mathrm{~K}$ by flowing thermostatted liquid through a series of bore-holes. The temperature of the gas at the intersection of the microwave lamp and laser beam was determined with a constantin-alumel thermocouple and is known to an accuracy of better than $2 \mathrm{~K}$.

\subsection{Generation of $\mathrm{OH}$}

$\mathrm{OH}$ generation is initiated by the photolysis of $\mathrm{NO}_{2}$ according to the following scheme (Carl and Crowley, 1998):

$$
\begin{aligned}
& \mathrm{NO}_{2}+h \nu(439.44 \mathrm{~nm}) \rightarrow \mathrm{NO}_{2}^{*} \\
& \mathrm{NO}_{2}^{*}+h \nu(439.44 \mathrm{~nm}) \rightarrow \mathrm{NO}_{2}^{* *} \\
& \mathrm{NO}_{2}^{* *} \rightarrow \mathrm{NO}+\mathrm{O}\left({ }^{1} \mathrm{D}\right) \\
& \mathrm{NO}_{2}^{* *} \rightarrow \mathrm{NO}+\mathrm{O}\left({ }^{3} \mathrm{P}\right) \\
& \mathrm{O}\left({ }^{1} \mathrm{D}\right)+\mathrm{H}_{2} \rightarrow \mathrm{OH}+\mathrm{H} \\
& \mathrm{H}+\mathrm{NO}_{2} \rightarrow \mathrm{OH}+\mathrm{NO}
\end{aligned}
$$

In all experiments the total pressure was 20 Torr ( 1 Torr $=1.333 \mathrm{hPa}$ ), the $\mathrm{NO}_{2}$ concentration was held constant at $\approx 5 \times 10^{14} \mathrm{~cm}^{-3}$ (occasionally determined optically), with the $\mathrm{H}_{2}$ concentration at about $2 \times 10^{16} \mathrm{~cm}^{-3}$. Under these conditions, the half lives for $\mathrm{OH}$ generation from reactions (7) and (8) are circa 1 and $8 \mu \mathrm{s}$, respectively. As we discuss in a previous publication (Carl and Crowley, 1998), OH is formed in vibrationally excited states in both reactions (7) and (8). The control experiments with $\mathrm{C}_{3} \mathrm{H}_{8}$ provide confirmation that either $\mathrm{OH}(v>0)$ is rapidly quenched by 
$\mathrm{NO}_{2}$ in our experiments (the rate constant for quenching of $\mathrm{OH}(v=1)$ by $\mathrm{NO}_{2}$ is $4.8 \times 10^{-11} \mathrm{~cm}^{3} \mathrm{~s}^{-1}$ (Smith and Williams, 1985) resulting in a half life of circa $40 \mu \mathrm{s}$ ), or that vibrational excitation in $\mathrm{OH}$ has no significant influence on the rate constants measured.

Typically, laser fluences of $\approx 20-40 \mathrm{~mJ} \mathrm{~cm}^{-2}$ were used to generate between $\approx 2 \times 10^{11}$ and $1 \times 10^{12} \mathrm{OH} \mathrm{cm}{ }^{-3}$. Experiments were also carried out in which the $248 \mathrm{~nm}$ photolysis of $\mathrm{HNO}_{3}$ was used as $\mathrm{OH}$ source:

$\mathrm{HNO}_{3}+h \nu(248 \mathrm{~nm}) \rightarrow \mathrm{OH}+\mathrm{NO}_{2}$

This source proved to be unsuitable for study of the reactions of $\mathrm{OH}$ with $\mathrm{C}_{3} \mathrm{H}_{7} \mathrm{I}$ due to the extensive dissociation of the iodides by the $248 \mathrm{~nm}$ laser light (see below), but was used for $\mathrm{OH}+\mathrm{C}_{3} \mathrm{H}_{8} . \quad n-\mathrm{C}_{3} \mathrm{H}_{7} \mathrm{I}$ (Aldrich, 99\%) and $i-\mathrm{C}_{3} \mathrm{H}_{7} \mathrm{I}$ (Aldrich, 99\%) were used after repeated degassing. The stated maximum $1 \%$ impurity in $n-\mathrm{C}_{3} \mathrm{H}_{7} \mathrm{I}$ is thought to be $i-\mathrm{C}_{3} \mathrm{H}_{7} \mathrm{I}$, and vice-versa. $\mathrm{C}_{3} \mathrm{H}_{8}$ (Linde, $99.95 \%$ ), $\mathrm{Ar}$ (Linde, 99.999\%), $\mathrm{H}_{2}$ (Linde, 99.999\%) and $\mathrm{NO}_{2}$ (purchased as $\mathrm{N}_{2} \mathrm{O}_{4}$, Merck, 99.5\%) were used without further purification.

\section{Results and discussion}

All experiments were carried out under pseudo first-order conditions, with the alkyl-iodide, RI, in large excess, i.e. [RI] $\gg[\mathrm{OH}]$. The decay of $\mathrm{OH}$ is then described by:

$$
[\mathrm{OH}]_{t}=[\mathrm{OH}]_{0} \exp \left\{-\left(k_{\mathrm{bi}}[\mathrm{RI}]+k_{\mathrm{NO} 2}\left[\mathrm{NO}_{2}\right]+d\right) t\right\}
$$

where $[\mathrm{OH}]_{t}$ is the $\mathrm{OH}$ concentration at time $=t$ after the laser pulse, $k_{\mathrm{bi}}$ the bimolecular rate constant for the reaction with RI, $k_{\mathrm{NO} 2}$ the rate constant for reaction of $\mathrm{OH}$ with $\mathrm{NO}_{2}$ and $d$ the rate constant for diffusion out of the reaction zone. The first-order decay constant, $k^{\prime}$ was obtained by non-linear least-squares fitting of the $\mathrm{OH}$ decays and is related to the desired rate constant, $k_{\mathrm{bi}}$ as shown in equation (11).

$k^{\prime}=k_{\mathrm{bi}}[\mathrm{RI}]+k_{\mathrm{NO} 2}\left[\mathrm{NO}_{2}\right]+d$

The loss of $\mathrm{OH}$ due to reaction with $\mathrm{NO}_{2}$ results in an intercept in the plot of $k^{\prime}$ versus [RI]. Efforts were therefore made to ensure that the concentration of $\mathrm{NO}_{2}$ (which was maintained by flow controller) remained constant during the course of experiments in which the decay of $\mathrm{OH}$ in various excess amounts of organic were measured. The spectral deconvolution procedure showed that $\left[\mathrm{NO}_{2}\right]$ was stable to $\approx 1 \%$ over such a measurement, which converts to a variation in the pseudo-first order decay constant of only \pm 60 $\mathrm{s}^{-1}$ in a total of between 800 and $5000 \mathrm{~s}^{-1}$, depending on the concentration (and identity) of the excess reactant. The observed small degree of scatter in the plots of $k^{\prime}$ versus [RI] confirm this.

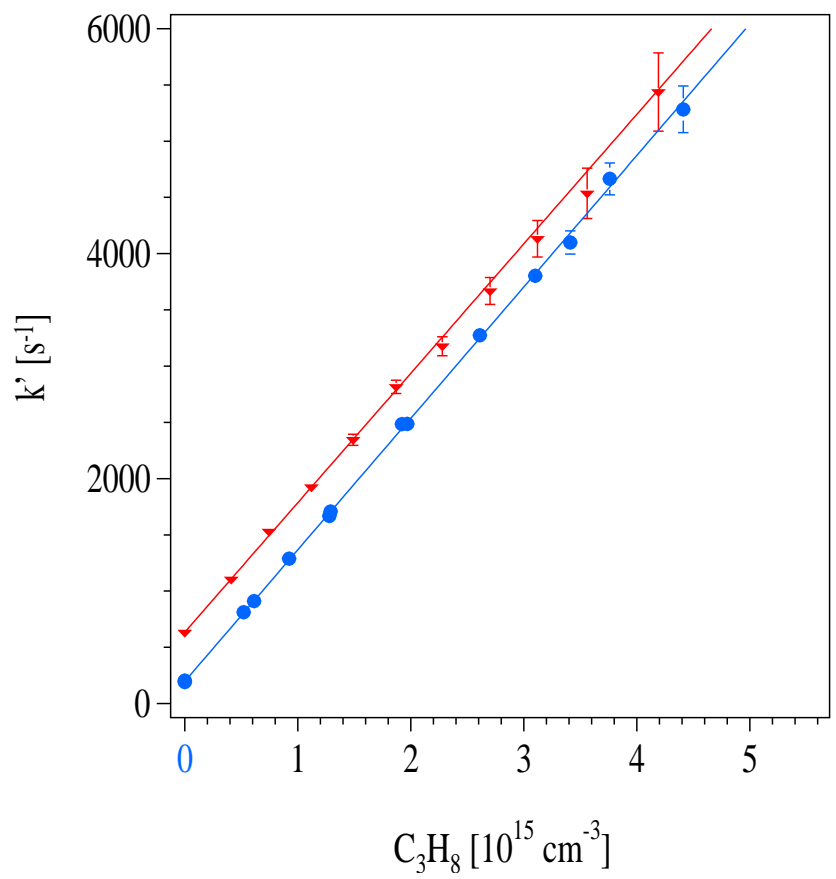

Fig. 2. Plot of pseudo-first order decay constant of $\mathrm{OH}$ versus [propane]. Circles represent data obtained using $248 \mathrm{~nm}$ photolysis of $\mathrm{HNO}_{3}$ as $\mathrm{OH}$ source, triangles are data points obtained using the two-photon $(439.44 \mathrm{~nm})$ dissociation of $\mathrm{NO}_{2}$ in the presence of $\mathrm{H}_{2}$ as $\mathrm{OH}$ source. The error bars are $2 \sigma$ statistical errors on $k^{\prime}$. The bimolecular rate constants obtained are $(1.17 \pm 0.01) \times 10^{-12}$ and $(1.15 \pm 0.03) \times 10^{-12} \mathrm{~cm}^{3} \mathrm{~s}^{-1}$, respectively $(2 \sigma$ precision $)$.

\section{$3.1 \mathrm{OH}+\mathrm{C}_{3} \mathrm{H}_{8}$}

The primary objective in re-measuring the rate constant for $\mathrm{OH}+\mathrm{C}_{3} \mathrm{H}_{8}$ was to test our experimental procedure, especially the use of two-photon dissociation of $\mathrm{NO}_{2}$ in the presence of $\mathrm{H}_{2}$ as the $\mathrm{OH}$ source, the reliability of which has not yet been completely assessed. For this reason a conventional OH source (248 nm photolysis of $\mathrm{HNO}_{3}$ ) was also used to enable direct comparison. Figure 1 shows the decay of $\mathrm{OH}$ in the presence of varying excess amounts of $\mathrm{C}_{3} \mathrm{H}_{8}$ using $\mathrm{NO}_{2}+2 h \nu(439.44 \mathrm{~nm})$ as $\mathrm{OH}$ source. As anticipated, the decay of $\mathrm{OH}$ is strictly exponential, and as shown in Fig. 2, its rate varies linearly with $\left[\mathrm{C}_{3} \mathrm{H}_{8}\right]$. The rate constant derived via equation (11) is $(1.15 \pm 0.03) \times 10^{-12} \mathrm{~cm}^{3} \mathrm{~s}^{-1}(2$ $\sigma$ precision). The overall accuracy of the rate constant is determined by the accuracy of the concentration measurement of the propane, and is estimated as $\approx 10 \%$. The final result is thus $(1.15 \pm 0.1) \times 10^{-12} \mathrm{~cm}^{3} \mathrm{~s}^{-1}$. Data obtained using reaction (9) as the $\mathrm{OH}$ source are also displayed in Fig. 2 (solid circles) and yield a rate constant $(1.17 \pm 0.1) \times 10^{-12}$ $\mathrm{cm}^{3} \mathrm{~s}^{-1}$. These results are clearly in excellent agreement with each other, and with the recommended literature value (Atkinson et al., 1997; DeMore et al., 1997) of $(1.1 \pm 0.2)$ $\times 10^{-12} \mathrm{~cm}^{3} \mathrm{~s}^{-1}$ providing validation of our experimental methods. 
Table 1. $298 \mathrm{~K}$ kinetic data for $\mathrm{OH}+$ propanes.

\begin{tabular}{llr}
\hline Reactant & OH source & $\begin{array}{r}k_{\mathrm{bi}} \pm 2 \sigma^{*} \\
10^{-12} \mathrm{~cm}^{3} \mathrm{~s}^{-1}\end{array}$ \\
\hline$n-\mathrm{C}_{3} \mathrm{H}_{7} \mathrm{I}$ & $\mathrm{NO}_{2}(439.44 \mathrm{~nm})$ & $1.47 \pm 0.02$ \\
$i-\mathrm{C}_{3} \mathrm{H}_{7} \mathrm{I}$ & $\mathrm{NO}_{2}(439.44 \mathrm{~nm})$ & $1.22 \pm 0.01$ \\
$i-\mathrm{C}_{3} \mathrm{H}_{7} \mathrm{I}$ & $\mathrm{HNO}_{3}(248 \mathrm{~nm})$ & $<1.48$ \\
$\mathrm{C}_{3} \mathrm{H}_{8}$ & $\mathrm{HNO}_{3}(248 \mathrm{~nm})$ & $1.17 \pm 0.01$ \\
$\mathrm{C}_{3} \mathrm{H}_{8}$ & $\mathrm{NO}_{2}(439.44 \mathrm{~nm})$ & $1.15 \pm 0.03$ \\
\hline
\end{tabular}

* Bimolecular rate constants for each temperature are obtained by least squares fitting to $k^{\prime}$ versus concentration of $\mathrm{C}_{3} \mathrm{H}_{8}, n-\mathrm{C}_{3} \mathrm{H}_{7} \mathrm{I}$ or $i-\mathrm{C}_{3} \mathrm{H}_{7} \mathrm{I}$. The fits were weighted by the $2 \sigma$ statistical errors on $k^{\prime}$ obtained for each decay profile. The estimated total errors in the rate constant are $\approx 5 \%$ for $n-\mathrm{C}_{3} \mathrm{H}_{7} \mathrm{I}$ and $i-\mathrm{C}_{3} \mathrm{H}_{7} \mathrm{I}$ and $10 \%$ for $\mathrm{C}_{3} \mathrm{H}_{8}$.

\section{$3.2 \mathrm{OH}+n-\mathrm{C}_{3} \mathrm{H}_{7} \mathrm{I}$ and $\mathrm{OH}+i-\mathrm{C}_{3} \mathrm{H}_{7} \mathrm{I}$}

Experiments on $\mathrm{OH}+i-\mathrm{C}_{3} \mathrm{H}_{7} \mathrm{I}$ were carried out using both $\mathrm{HNO}_{3}$ photolysis at $248 \mathrm{~nm}$ and $\mathrm{NO}_{2} / \mathrm{H}_{2}$ photolysis at $439.44 \mathrm{~nm}$, data for $\mathrm{OH}+n-\mathrm{C}_{3} \mathrm{H}_{7} \mathrm{I}$ was obtained using the $\mathrm{NO}_{2} / \mathrm{H}_{2}$ photolysis source only. The concentrations of the iodo-propanes were determined by absorption spectroscopy (see above) and least squares fitting to known UV absorption spectra (Roehl et al., 1997). The quality of the fits was such that the estimated errors in concentration are less than $5 \%$, including errors in the absorption cross-sections close to the maxima.

The first-order decays of $\mathrm{OH}$ were similar in quality to those shown for $\mathrm{C}_{3} \mathrm{H}_{8}$ and displayed the expected linear dependence on the concentration of the iodo-propane. For a given $i-\mathrm{C}_{3} \mathrm{H}_{7} \mathrm{I}$ concentration, the value of $k^{\prime}$ was found to be independent of laser fluence when varied by a factor of about 3 , and thus initial $[\mathrm{OH}]$ by a factor $\approx 10$ for those experiments carried out using $\mathrm{NO}_{2} / \mathrm{H}_{2}$ photolysis. However, when the photolysis of $\approx 1 \times 10^{15} \mathrm{HNO}_{3} \mathrm{~cm}^{-3}$ at $248 \mathrm{~nm}$ was used as the $\mathrm{OH}$ source, the first order decay constant was found to be strongly dependent on laser fluence. As an example, increasing the $248 \mathrm{~nm}$ laser fluence from $\approx 2 \mathrm{~mJ}$ $\mathrm{cm}^{-2}$ to $\approx 8 \mathrm{~mJ} \mathrm{~cm}^{-2}$ resulted in an increase in the measured first order decay constant (for a fixed $i-\mathrm{C}_{3} \mathrm{H}_{7} \mathrm{I}$ ) from $1060 \pm 10 \mathrm{~s}^{-1}$ to $1360 \pm 10 \mathrm{~s}^{-1}$. This is attributed to the efficient photo-fragmentation of $i-\mathrm{C}_{3} \mathrm{H}_{7} \mathrm{I}$ at $248 \mathrm{~nm}$ where it absorbs strongly $\left(\sigma \approx 1 \times 10^{-18} \mathrm{~cm}^{2}\right)$.

$i-\mathrm{C}_{3} \mathrm{H}_{7} \mathrm{I}+h \nu(248 \mathrm{~nm}) \rightarrow i-\mathrm{C}_{3} \mathrm{H}_{7}+\mathrm{I}$

and a rapid reaction (Tsang, 1988) of $\mathrm{OH}$ with the radical product:

$\mathrm{C}_{3} \mathrm{H}_{7}+\mathrm{OH} \rightarrow$ products
This problem was clearly not encountered when using 439.44 $\mathrm{nm}$ radiation to generate $\mathrm{OH}$ radicals as $i-\mathrm{C}_{3} \mathrm{H}_{7} \mathrm{I}$ does not absorb at this wavelength, and highlights the advantages of using pulsed visible radiation instead of UV radiation, as only very few small molecules have absorption spectra that extend beyond $400 \mathrm{~nm}$. The data obtained with $\mathrm{HNO}_{3}+$ $248 \mathrm{~nm}$ photolysis therefore only define an upper limit to the rate constant for $\mathrm{OH}+i-\mathrm{C}_{3} \mathrm{H}_{7} \mathrm{I}$ (see Table 1). Data obtained with $\mathrm{NO}_{2} / \mathrm{H}_{2}$ photolysis at $439.44 \mathrm{~nm}$ are summarised in Table 1, and the plot of $k^{\prime}$ versus concentration of iodopropane is displayed in Fig. 3. The rate constants obtained are $(1.47 \pm 0.08) \times 10^{-12} \mathrm{~cm}^{3} \mathrm{~s}^{-1}$ and $(1.22 \pm 0.06) \times$ $10^{-12} \mathrm{~cm}^{3} \mathrm{~s}^{-1}$ for $\mathrm{OH}$ with $n-\mathrm{C}_{3} \mathrm{H}_{7} \mathrm{I}$ and $i-\mathrm{C}_{3} \mathrm{H}_{7} \mathrm{I}$, respectively (errors are $2 \sigma$ precision plus $5 \%$ estimated systematic error in concentration measurement). As $i-\mathrm{C}_{3} \mathrm{H}_{7} \mathrm{I}$ and (by analogy) $n-\mathrm{C}_{3} \mathrm{H}_{7} \mathrm{I}$ react rapidly with $\mathrm{O}\left({ }^{3} \mathrm{P}\right.$ ) (Gilles et al., 1996), it is necessary to assess the potential impact of this on the reported rate constants. The products of the reaction of $\mathrm{O}\left({ }^{3} \mathrm{P}\right)$ with the iodo-propanes are $\mathrm{IO}, \mathrm{HOI}, \mathrm{C}_{3} \mathrm{H}_{6}$, and $\mathrm{C}_{3} \mathrm{H}_{7}$ (Klaasen et al., 1996). By analogy with the reaction of $\mathrm{O}\left({ }^{3} P\right.$ $+\mathrm{C}_{2} \mathrm{H}_{5} \mathrm{I}$ (Monks et al., 1995) reaction (14a) is expected to dominate with a branching ratio close to 0.9 .

$$
\begin{aligned}
\mathrm{O}\left({ }^{3} \mathrm{P}\right)+\mathrm{C}_{3} \mathrm{H}_{7} \mathrm{I} & \rightarrow \mathrm{HOI}+\mathrm{C}_{3} \mathrm{H}_{6} \\
& \rightarrow \mathrm{IO}+\mathrm{C}_{3} \mathrm{H}_{7}
\end{aligned}
$$

$\mathrm{OH}$ is expected to react rapidly not only with propyl radicals (see above) but, by analogy with $\mathrm{BrO}$ and $\mathrm{ClO}$, also with $\mathrm{IO}$ radicals (DeMore et al., 1997). The potential perturbation of the $\mathrm{OH}$ kinetics due to the formation of reactive products was investigated by varying the pulse energy at $439.44 \mathrm{~nm}$ and thus the initial $\mathrm{OH}$ and $\mathrm{O}\left({ }^{3} \mathrm{P}\right)$ concentrations by a factor of 10. This had no effect on the resulting pseudo-first order decays, ruling out a significant secondary loss of $\mathrm{OH}$. The potential enhancement in measured rate constants for both $n-\mathrm{C}_{3} \mathrm{H}_{7} \mathrm{I}$ and $i-\mathrm{C}_{3} \mathrm{H}_{7} \mathrm{I}$ due to the presence of $\mathrm{I}_{2}$ impurity was also examined. The rate constant for reaction between $\mathrm{OH}$ and $\mathrm{I}_{2}(15)$ is at $\approx 2 \times 10^{-10} \mathrm{~cm}^{3} \mathrm{~s}^{-1}$ very large, and $\mathrm{I}_{2}$ impurity at the percent level would result in a factor of two overestimation of the true rate constant.

$\mathrm{OH}+\mathrm{I}_{2} \rightarrow \mathrm{HOI}+\mathrm{I}$

For this reason, the visible absorption by highly concentrated mixtures of the alkyl iodides in the region where $\mathrm{I}_{2}$ absorbs strongly was examined for traces of $\mathrm{I}_{2}$. None were found, and we were able to set an upper limit to the fractional concentration of $\mathrm{I}_{2}$ of $3 \times 10^{-4}$ in $n-\mathrm{C}_{3} \mathrm{H}_{7} \mathrm{I}$ and $i-\mathrm{C}_{3} \mathrm{H}_{7} \mathrm{I}$. This implies an upper limit to the contribution to the overall $\mathrm{OH}$ decay (and thus to $k_{1}$ and $k_{2}$ ) of just $3 \%$.

At $(1.47 \pm 0.08) \times 10^{-12} \mathrm{~cm}^{3} \mathrm{~s}^{-1}$ the rate constant obtained for $n-\mathrm{C}_{3} \mathrm{H}_{7} \mathrm{I}$ is $\approx 20$ percent larger than that for $i-\mathrm{C}_{3} \mathrm{H}_{7} \mathrm{I}\left((1.22 \pm 0.06) \times 10^{-12} \mathrm{~cm}^{3} \mathrm{~s}^{-1}\right)$. This trend is to be expected if one considers that the overall rate of $\mathrm{H}$ abstraction from the $\mathrm{CH}_{2}$ group in propane is a factor 4 faster than from the $\mathrm{CH}_{3}$ groups (Talukdar et al. 1994) implying a 
$298 \mathrm{~K}$ rate constant of $3.7 \times 10^{-14} \mathrm{~cm}^{3} \mathrm{~s}^{-1}$ per primary $\mathrm{H}$-atom and $4.4 \times 10^{-13} \mathrm{~cm}^{3} \mathrm{~s}^{-1}$ per secondary H-atom. Replacement of a primary $\mathrm{H}$-atom with I (as for $n-\mathrm{C}_{3} \mathrm{H}_{7} \mathrm{I}$ ) should not reduce the overall rate of abstraction as much as replacing one of the more reactive secondary $\mathrm{H}$-atoms (as in $\left.i-\mathrm{C}_{3} \mathrm{H}_{7} \mathrm{I}\right)$. The fact that both $n-\mathrm{C}_{3} \mathrm{H}_{7} \mathrm{I}$ and $i-\mathrm{C}_{3} \mathrm{H}_{7} \mathrm{I}$ react more rapidly with $\mathrm{OH}$ than calculated from the remaining number of primary and secondary $\mathrm{H}$-atoms, suggests that the presence of the I-atom results in a weakening of the neighbouring $\mathrm{C}-\mathrm{H}$ bonds as seen for the reactions of $\mathrm{CH}_{3} \mathrm{I}$ with $\mathrm{OH}$ $\left(\mathrm{k}=7.2 \times 10^{-14} \mathrm{~cm}^{3} \mathrm{~s}^{-1}\right.$ at $\left.298 \mathrm{~K}\right)$ and $\mathrm{CH}_{4}+\mathrm{OH}(\mathrm{k}=6.3$ $\times 10^{-15} \mathrm{~cm}^{3} \mathrm{~s}^{-1}$ at $298 \mathrm{~K}$ ) (DeMore et al., 1997). An alternative explanation is that the reaction partially proceeds via a complex mechanism in which $\mathrm{OH}$ attack at the $\mathrm{C}$-I bond can lead to products, in a similar fashion to reactions of $\mathrm{O}\left({ }^{3} \mathrm{P}\right)$ with alkyl-iodides (Gilles et al., 1996; Klaasen et al., 1996) (see above) and $\mathrm{OH}$ with $\mathrm{CF}_{3} \mathrm{I}$ (Brown et al., 1990; Berry et al., 1998). There is also theoretical evidence supporting a complex mechanism for the reaction of $\mathrm{OH}$ with haloethanes (Sekušak and Sabljic, 1997).

$$
\begin{aligned}
& \mathrm{OH}+\mathrm{CF}_{3} \mathrm{I} \rightarrow \mathrm{HOI}+\mathrm{CF}_{3} \\
& \mathrm{OH}+\mathrm{C}_{3} \mathrm{H}_{7} \mathrm{I} \rightarrow \mathrm{HOI}+\mathrm{C}_{3} \mathrm{H}_{7}
\end{aligned}
$$

However, the latest estimates for the heat of formation of HOI (Berry et al., 1998) suggest that reaction (17a) is endothermic by $>20 \mathrm{kJmol}^{-1}$ for both $n-\mathrm{C}_{3} \mathrm{H}_{7} \mathrm{I}$ and $i-\mathrm{C}_{3} \mathrm{H}_{7} \mathrm{I}$ and therefore unlikely to be significant in the present experiments at $298 \mathrm{~K}$, or in the atmosphere. As the present study gives no indications to the contrary, we assume that the reaction proceeds via $\mathrm{H}$-atom abstraction to give $\mathrm{H}_{2} \mathrm{O}$ and an iodine containing alkyl radical as products.

$\mathrm{OH}+\mathrm{C}_{3} \mathrm{H}_{7} \mathrm{I} \rightarrow \mathrm{H}_{2} \mathrm{O}+\mathrm{C}_{3} \mathrm{H}_{6} \mathrm{I}$

\section{Conclusions and atmospheric implications}

The overall rate constant for the reaction of $\mathrm{OH}$ with propane was measured using both $248 \mathrm{~nm}$ photolysis of $\mathrm{HNO}_{3}$ and two-photon $(439.44 \mathrm{~nm})$ dissociation of $\mathrm{NO}_{2}$ in the presence of $\mathrm{H}_{2}$ as $\mathrm{OH}$ sources. Within experimental scatter both methods give the same result $\left(k=(1.15 \pm 0.06) \times 10^{-12}\right.$ and $(1.17 \pm 0.06) \times 10^{-12} \mathrm{~cm}^{3} \mathrm{~s}^{-1}$, respectively), and are in excellent agreement with the literature recommendation. The $298 \mathrm{~K}$ rate constants obtained for $n-\mathrm{C}_{3} \mathrm{H}_{7} \mathrm{I}$ and $i-\mathrm{C}_{3} \mathrm{H}_{7} \mathrm{I}$ are $(1.47 \pm 0.08)$ and $(1.22 \pm 0.06) \times 10^{-12} \mathrm{~cm}^{3} \mathrm{~s}^{-1}$, respectively. These rate constants can be used to assess the relative importance of $\mathrm{OH}$ reaction and photolysis as destruction pathways for $n-\mathrm{C}_{3} \mathrm{H}_{7} \mathrm{I}$ and $i-\mathrm{C}_{3} \mathrm{H}_{7} \mathrm{I}$ in the atmosphere. The J-values for $n-\mathrm{C}_{3} \mathrm{H}_{7} \mathrm{I}$ and $i-\mathrm{C}_{3} \mathrm{H}_{7} \mathrm{I}$, calculated for a $40^{\circ}$ solar zenith angle are reported as $\approx 8 \times 10^{-6} \mathrm{~s}^{-1}$ and $2 \times 10^{-5} \mathrm{~s}^{-1}$ respectively (Roehl et al., 1997). Using the rate constants above, and assuming a $\mathrm{OH}$ concentration of $5 \times 10^{6} \mathrm{~cm}^{-3}$ (Brauers et al., 2001), we calculate a loss

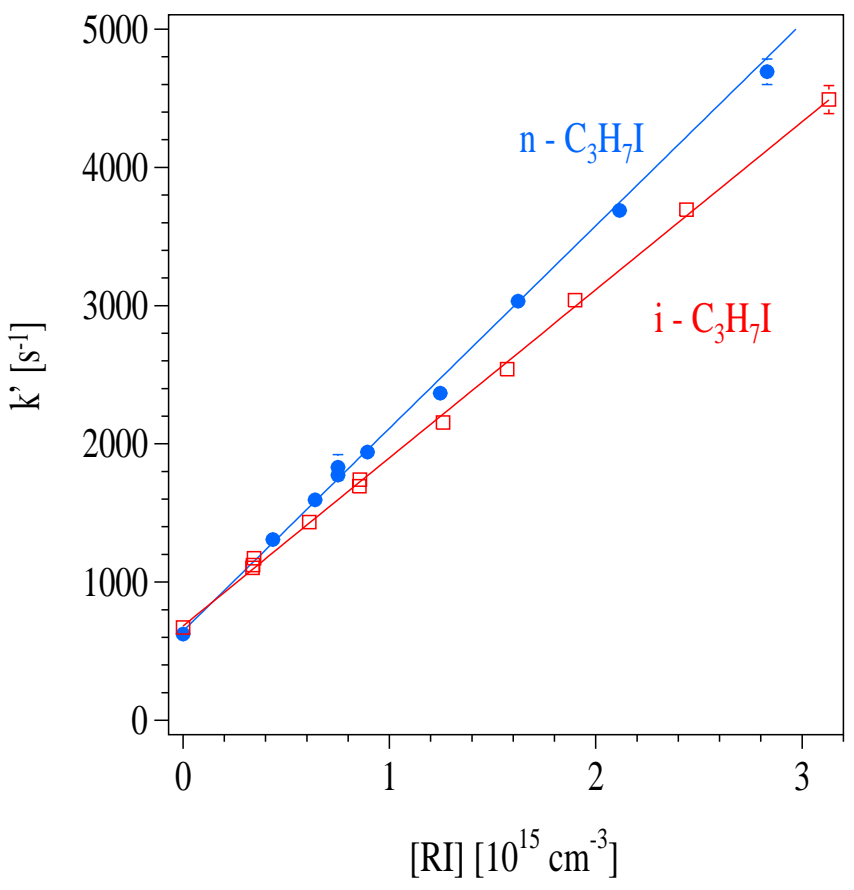

Fig. 3. Plot of pseudo-first order decay constant of $\mathrm{OH}$ versus [propyl-iodide]. Solid circles, $n-\mathrm{C}_{3} \mathrm{H}_{7} \mathrm{I}\left(k_{1}=1.47 \pm 0.02 \times\right.$ $\left.10^{-13} \mathrm{~cm}^{3} \mathrm{~s}^{-1}\right)$; open squares, $i-\mathrm{C}_{3} \mathrm{H}_{7} \mathrm{I}\left(k_{2}=1.22 \pm 0.01 \times\right.$ $10^{-13} \mathrm{~cm}^{3} \mathrm{~s}^{-1}$ ), $2 \sigma$ precision. The error bars are $2 \sigma$ statistical errors on $k^{\prime}$, overall errors in the bimolecular rate constants are estimated as $\approx 5 \%$, related mainly to errors in the absorption cross sections of $n-\mathrm{C}_{3} \mathrm{H}_{7} \mathrm{I}$ and $i-\mathrm{C}_{3} \mathrm{H}_{7} \mathrm{I}$.

rate of about $7 \times 10^{-6} \mathrm{~s}^{-1}$ and $6 \times 10^{-6} \mathrm{~s}^{-1}$ for $n-\mathrm{C}_{3} \mathrm{H}_{7} \mathrm{I}$ and $i-\mathrm{C}_{3} \mathrm{H}_{7} \mathrm{I}$, respectively due to reaction with $\mathrm{OH}$. For both $n-\mathrm{C}_{3} \mathrm{H}_{7} \mathrm{I}$ and $i-\mathrm{C}_{3} \mathrm{H}_{7} \mathrm{I}$ the loss rate due to reaction with $\mathrm{OH}$ is therefore of similar magnitude to that by photolysis and should be incorporated into estimates of the source strength of reactive iodine in the marine boundary layer. The $298 \mathrm{~K}$ rate constant for reaction of $n-\mathrm{C}_{3} \mathrm{H}_{7} \mathrm{I}$ and $i-\mathrm{C}_{3} \mathrm{H}_{7} \mathrm{I}$ with $\mathrm{Cl}$ have recently been measured (Cotter et al., 2001) and found to be $6.6 \times 10^{-11}$ and $4.6 \times 10^{-11} \mathrm{~cm}^{3} \mathrm{~s}^{-1}$, respectively. The $\mathrm{Cl} / \mathrm{OH}$ rate constant ratios for $n-\mathrm{C}_{3} \mathrm{H}_{7} \mathrm{I}$ and $i-\mathrm{C}_{3} \mathrm{H}_{7} \mathrm{I}$ are thus 45 and 38, respectively. Estimations of the relative, average $\mathrm{OH} / \mathrm{Cl}$-atom concentrations in the marine boundary layer vary between low values (Pszenny et al., 1993; Singh et al., 1996; Wingenter et al., 1996) of $\approx 10-100$ to high values (Singh et al., 1996; Rudolph et al., 1997) of $>1000$. Thus, in air masses where the activation of chlorine from sea-salt is possible, the reaction of $\mathrm{Cl}$ atoms with $n-\mathrm{C}_{3} \mathrm{H}_{7} \mathrm{I}$ and $i-\mathrm{C}_{3} \mathrm{H}_{7} \mathrm{I}$ may, during part of the day, compete with the $\mathrm{OH}$ reactions and photolysis. Daily averaged $\mathrm{OH}$ concentrations over the MBL are however likely to exceed those of $\mathrm{Cl}$ so that $\mathrm{OH}$ reactions will generally represent the main (nonphotolytic) reactive sink.

The products of the $\mathrm{OH}$ reactions and photolysis of $\mathrm{C}_{3} \mathrm{H}_{7} \mathrm{I}$ are different. Whereas the photolysis of the alkyl iodide 
yields an I-atom, the reaction with $\mathrm{OH}$ probably results in formation of an iodine containing alkyl radical (see above) that can react with $\mathrm{O}_{2}$ to form a peroxy radical, the nature of which will depend on the position of the I-atom in the alkyl iodide, and on the position of $\mathrm{OH}$ attack. The fate of the peroxy radicals will be reaction with NO in marine air masses influenced by pollution to form carbonyl compounds and, through a series of secondary reactions, will generally lead to the release of the I-atom to the gas phase. In air masses where $\mathrm{NO}$ is low, the reaction of the peroxy radical with $\mathrm{HO}_{2}$ will dominate to form peroxides, which may eventually also release I-atoms via their photochemical oxidation, or which may be lost to the ocean by deposition. Experimental studies of product formation in the reactions of $\mathrm{OH}$ with $n-\mathrm{C}_{3} \mathrm{H}_{7} \mathrm{I}$ and $i-\mathrm{C}_{3} \mathrm{H}_{7} \mathrm{I}$ are required to elucidate the fate and impact of these molecules on the iodine chemistry of the marine boundary layer.

Acknowledgements. The authors thank the European Union for financial support within the LEXIS project (ENV4-CT95-0013).

\section{References}

Alicke, B., Hebestreit, K., Stutz, J., and Platt, U.: Iodine oxide in the marine boundary layer, Nature, 397, 572-573, 1999.

Allan, B. J., McFiggans, G., Plane, J. M. C., and Coe, H.: Observations of iodine monoxide in the remote marine boundary layer, J. Geophys. Res., 105, 14363-14369, 2000.

Atkinson, R., Baulch, D. L., Cox, R. A., Hampson, R. F. J., Kerr, J. A., Rossi, M. J., and Troe, J.: Evaluated kinetic and photochemical data for atmospheric chemistry: supplement VI. IUPAC subcommittee on gas kinetic data evaluation for atmospheric chemistry, J. Phys. Chem. Ref. Data, 26, 1329-1499, 1997.

Berry, R. J., Yuan, J., Misra, A., and Marshall, P.: Experimental and computational investigations of the reaction of $\mathrm{OH}$ with $\mathrm{CF}_{3} \mathrm{I}$ and the enthalpy of formation of HOI, J. Phys. Chem., A 102, 5182-5188, 1998.

Brauers, T., Hausmann, M., Bister, A., Kraus, A., and Dorn, H. P.: $\mathrm{OH}$ radicals in the boundary layer of the Atlantic Ocean 1. Measurements by long-path laser absorption spectroscopy, J. Geophys. Res., 106, 7399-7414, 2001.

Brown, A. C., Canosa-Mas, C. E., and Wayne, R. P.: A Kineticstudy of the reactions of $\mathrm{OH}$ with $\mathrm{CH}_{3} \mathrm{I}$ and $\mathrm{CF}_{3} \mathrm{I}$, Atmos. Environ., 24, 361-367, 1990.

Carl, S. A. and Crowley, J. N.: Sequential two (blue) photon absorption by $\mathrm{NO}_{2}$ in the presence of $\mathrm{H}_{2}$ as a source of $\mathrm{OH}$ in pulsed photolysis kinetic studies: Rate constants for reaction of $\mathrm{OH}$ with $\mathrm{CH}_{3} \mathrm{NH}_{2},\left(\mathrm{CH}_{3}\right)_{2} \mathrm{NH},\left(\mathrm{CH}_{3}\right)_{3} \mathrm{~N}$, and $\mathrm{C}_{2} \mathrm{H}_{5} \mathrm{NH}_{2}$ at 295 K, J. Phys. Chem., A 102, 8131-8141, 1998.

Carpenter, L. J., Sturges, W. T., Penkett, S. A., Liss, P. S., Alicke, B., Hebestreit, K., and Platt, U.: Short-lived alkyl iodides and bromides at Mace Head, Ireland: Links to biogenic sources and halogen oxide production, J. Geophys. Res., 104, 1679-1689, 1999.

Chameides, W. L. and Davis, D. D.: Iodine - its possible role in tropospheric photochemistry, J. Geophys. Res., 85, 7383-7398, 1980.
Chatfield, R. B. and Crutzen, P. J.: Are there interactions of iodine and sulfur species in marine air photochemistry, J. Geophys. Res., 95, 22 319-22 341, 1990.

Cotter, E. S. N., Booth, N. J., Canosa-Mas, C. E., Gray, D. J., Shallcross, D. E., and Wayne, R. P.: Reactions of $\mathrm{Cl}$ atoms with $\mathrm{CH}_{3} \mathrm{I}$, $\mathrm{C}_{2} \mathrm{H}_{5} \mathrm{I}, 1-\mathrm{C}_{3} \mathrm{H}_{7} \mathrm{I}, 2-\mathrm{C}_{3} \mathrm{H}_{7} \mathrm{I}$ and $\mathrm{CF}_{3} \mathrm{I}$ : kinetics and atmospheric relevance, Phys. Chem. Chem. Phys., 3, 402-408, 2001.

Crowley, J. N., Campuzano-Jost, P., and Moortgat, G. K.: Temperature dependent rate constants for the gas-phase reaction between $\mathrm{OH}$ and $\mathrm{CH}_{3} \mathrm{OCl}$, J. Phys. Chem., 100, 3601-3606, 1996.

Crutzen, P. J.: Atmospheric interactions-homogeneous gas reactions of $\mathrm{C}, \mathrm{N}$, and $\mathrm{S}$ containing compounds, in: The major biogeochemical cycles and their interactions, (Eds) Bolin, B. and Cook, R. B., 67-113, J. Wiley, Chichester, New York, 1983.

Davis, D., Crawford, J., Liu, S., McKeen, S., Bandy, A., Thornton, D., Rowland, F., and Blake, D.: Potential impact of iodine on tropospheric levels of ozone and other critical oxidants, J. Geophys. Res., 101, 2135-2147, 1996.

DeMore, W. B., Sander, S. P., Golden, D. M., Hampson, R. F., Kurylo, M. J., Howard, C. J., Ravishankara, A. R., Kolb, C. E., and Molina, M. J.: Chemical Kinetics and Photochemical Data for Use in Stratospheric Modelling, No 12, Jet Propulsion Laboratory, Pasadena, CA, 1997.

Gilles, M. K., Turnipseed, A. A., Talukdar, R. K., Rudich, Y., Villalta, P. W., Huey, L. G., Burkholder, J. B., and Ravishankara, A. R.: Reactions of $\mathrm{O}\left({ }^{3} \mathrm{P}\right)$ with alkyl iodides: Rate coefficients and reaction products, J. Phys. Chem., 100, 14 005-14 015, 1996.

Happell, J. D. and Wallace, D. W. R.: Methyl iodide in the Greenland/Norwegian Seas and the tropical Atlantic Ocean: evidence for photochemical production, Geophys. Res. Lett., 23, 21052108, 1996.

Jenkin, M. E.: The tropospheric chemistry of ozone in the polar regions, in NATO ASI Series Vol. I7, (Eds) Niki, H. and Becker, K. H., Springer-Verlag, Berlin, 1993.

Jenkin, M. E., Cox, R. A., and Candeland, D. E.: Photochemical Aspects of Tropospheric Iodine Behaviour, J. Atmos. Chem., 2, 359-375, 1985.

Klaasen, J. J., Lindner, J., and Leone, S. R.: Observation of the $\mathrm{v}_{1}$ $\mathrm{OH}(\mathrm{OD})$ stretch of HOI and DOI by Fourier transform infrared emission spectroscopy, J. Chem. Phys., 104, 7403-7411, 1996.

McFiggans, G., Plane, J. M. C., Allan, B. J., Carpenter, L. J., Coe, H., and O'Dowd, C.: A modeling study of iodine chemistry in the marine boundary layer, J. Geophys. Res., 105, 14371-14385, 2000.

Monks, P. S., Stief, L. J., Tardy, D. C., Liebman, J. F., Zhang, Z., Kuo, S.-C., and Klemm, R. B.: Discharge flow-photoionization mass spectrometric study of HOI: Photoionization efficiency spectrum and ionization energy, J. Phys. Chem., 99, 16566$16570,1995$.

Pszenny, A. A. P., Keene, W. C., Jacob, D. J., Fan, S., Maben, J. R., Zetwo, M. P., Springer-Young, M., and Galloway, J. N.: Evidence of inorganic chlorine gases other than hydrogen chloride in marine surface air, Geophys. Res. Lett., 20, 699-702, 1993.

Roehl, C. M., Burkholder, J. B., Moortgat, G. K., Ravishankara, A. R., and Crutzen, P. J.: Temperature dependence of UV absorption cross sections and atmospheric implications of several alkyl iodides, J. Geophys. Res., 102, 12 819-12 829, 1997.

Rudolph, J., Ramacher, B., Plass-Dülmer, C., Müller, K.-P., and Koppmann, R.: The indirect determination of chlorine atom con- 
centration in the troposphere from changes in the patterns of nonmethane hydrocarbons, Tellus 49B, 592-601, 1997.

Schall, C. and Heumann, K. G.: GC determination of volatile organoiodine and organobromine compounds in Arctic seawater and air samples, Fresenius' J. Anal. Chem., 346, 717-722, 1993.

Sekušak, S. and Sabljic, A.: The role of complexes in hydrogen abstraction from haloethanes by the hydroxyl radical. A case of guided reactions, Chem. Phys. Lett., 272, 353-360, 1997.

Singh, H. B., Salas, L. J., and Stiles, R. E.: Methyl halides in and over the Eastern Pacific $\left(40^{\circ} \mathrm{N}-32^{\circ} \mathrm{S}\right)$, J. Geophys. Res., 88, 3684-3690, 1983.

Singh, H. B., Thakur, A. N., Chen, Y. E., and Kanakidou, M.: Tetrachloroethylene as an indicator of low $\mathrm{Cl}$ atom concentrations in the troposphere, Geophys. Res. Lett., 23, 1529-1532, 1996.

Singh, H. N., Gregory, G. L., Anderson, B., Browell, E., Sachse, G. W., Davis, D. D., Crawford, J., Bradshaw, J. D., Talbot, R., Blake, D. R., Thornton, D., Newell, R., and Merrill, J.: Low ozone in the marine boundary layer of the tropical Pacific ocean: photochemical loss, chlorine atoms, and entrainment, J. Geophys. Res., 101, 1907-1917, 1996.

Smith, I. W. and Williams, M. D.: Vibrational-relaxation of
$\mathrm{OH}(\mathrm{v}=1)$ and $\mathrm{OD}(\mathrm{v}=1)$ by $\mathrm{HNO}_{3}, \mathrm{DNO}_{3}, \mathrm{H}_{2} \mathrm{O}$, $\mathrm{NO}$ and $\mathrm{NO}_{2}$, J. Chem. Soc. Faraday Trans., 2, 81, 1849-1860, 1985.

Stutz, J., Hebestreit, K., Alicke, B., and Platt, U.: Chemistry of halogen oxides in the troposphere: Comparison of model calculations with recent field data, J. Atmos. Chem., 34, 65-85, 1999.

Talukdar, R. K., Mellouki, A., Gierczak, T., Barone, S., Chiang, S.-Y., and Ravishankara, A. R.: Kinetics of the reactions of $\mathrm{OH}$ with alkanes, Int. J. Chem. Kinet., 26, 973-990, 1994.

Tsang, W.: Chemical kinetic data base for combustion chemistry. Part 3. Propane, J. Phys. Chem. Ref., Data 17, 887, 1988.

Vogt, R., Sander, R., von Glasow, R., and Crutzen, P. J.: Iodine chemistry and its role in halogen activation and ozone loss in the marine boundary layer: a model study, J. Atmos. Chem., 32, 375-395, 1999.

Wingenter, O. W., Kubo, M. K., Blake, N. J., Smith, Jr., T. W., Blake, D. R., and Rowland, F. S.: Hydrocarbon and halocarbon measurements as photochemical and dynamical indicators of atmospheric hydroxyl, atomic chlorine, and vertical mixing obtained during Lagrangian flights, J. Geophys. Res., 101, 43314340, 1996. 